\title{
Is water an indulgence? What marketing messages say about water use in tourism accommodation in a dryland region
}

\author{
L. V. Lehmann \\ University of Ballarat, Australia
}

\begin{abstract}
Developing an approach to sustainable use of freshwater in the tourism industry has become increasingly critical, particularly in dryland regions. To date there has been little research into the messages regarding water management that operators of tourism accommodation enterprises in dryland regions present to potential visitors through the marketing of their business.

While there is no question that marketing for tourism accommodation is designed to increase the level of occupancy and hence the profitability of each enterprise, there are a range of messages included in the promotion that are designed to have an impact on the decision making process of the potential visitor. Messages regarding freshwater use in that accommodation enterprise may reflect the attitude of that operator to sustainable freshwater management. It may also be a reflection of the type of market sector that the accommodation operator is trying to appeal to in their promotion.

After more than ten years of drought, the Grampians and Wimmera Mallee regions make an ideal location for a case study on sustainable freshwater management in the tourism accommodation sector. Over that time there has been limited research to assess the impact of an increasingly water constrained environment on the tourism accommodation sector or on how these enterprises have managed changes to their freshwater resources. The results of a content analysis of promotional media, such as brochures, visitor guides and websites, including text, pictures and logos, are presented in this paper.
\end{abstract}

Keywords: sustainable tourism, tourism water consumption. 


\section{Introduction}

It was in 2003 that the United Nations World Tourism Organisation (UNWTO [1]) first recognised that fresh water is one of the most critical and scarce natural resources for the tourism industry. This was followed up by further recognition at the 2007 conference on the impact of climate change on tourism at Davos (UNWTO [2]) and in recent years by the United Nations Environment Program (UNEP [3]). More recently, in 2009, The Jackson Report [4], informing the national long-term tourism strategy for Australia, highlighted water security problems in southern and eastern Australia as one of the major impacts of climate change by 2030 . While these reports highlighted water issues for tourism in the context of climate change, there is no doubt that issues relating to water, and its role in sustainable tourism, are becoming more significant in terms of management and long term planning.

It has long been appreciated that that many water features in a landscape play a significant role in the decision by visitors to visit particular destinations (Hadwen et al. [5]). Further, water quality, clarity and accessibility have an impact on the activities and experiences of many visitors to freshwater environments. It is also well documented that many destinations and attractions rely on a consistent supply of freshwater in order to maintain a viable tourism sector (Anderson [6], Cooper [7], Touhino [8], Goossen [9], Prideaux et al. [10], Efurt-Cooper [11]).

In terms of water management in the tourism accommodation sector there has been some focus on consumptive use, which was demonstrated in a recent Spanish case studies that highlighted the contrasts in water use by tourists using different types of accommodation facilities (Rico-Amoros, et al. [12]). This research concluded that different types and ages of accommodation can have a significant impact on individual tourist water consumption. The study contrasts the more modern resort style accommodation facilities that have a higher water use with older style high rise mass tourism or camp style facilities (Rico-Amoros et al. [12]).

From a tourism accommodation business perspective, water is seen as a significant issue to the tourism industry. The International Centre for Responsible Tourism at Leeds Metropolitan University (Goodwin and Walters [13]) reported that water shortages were affecting businesses. While these issues have been identified there has been very little research that considers water from a more holistic perspective. This paper focuses how marketing and promotion in tourism impact on the perception of guests to water use while they are on holiday or how changes can be made to guest behaviour to reduce water consumption during holidays.

\section{The promotion of water in tourism}

In developing an understanding of the role that water plays in attracting visitors to a region or destination, it has become apparent that water, by its very nature is 
ubiquitous in tourism. Water plays a range of different roles across the tourism sector and can be interpreted in a number of different ways.

While the attraction of water in coastal and tropical tourism regions is obvious, even those regions described as dryland or semi-arid inland regions are still centred around significant natural fresh water features such as water falls, lakes and rivers (Hudson [14]). This is the case even in semi-arid or dryland landscapes where water is not abundant and sometimes ephemeral (Hadwen et al. [5]). Too little or too much water can have a dramatic impact on a destination's ability to provide a consistent and safe tourism product. Changes in water availability can also have a dramatic impact on the ability of a destination to attract visitors, particularly those that focus on water-based tourism attractions.

Water has significant recreational attributes for tourism activities such as boating, fishing and hunting. In recent years, many tourism authorities have to also started recognise the value of promoting and marketing tourism products relating to golf, health and wellbeing and food and wine tourism (Tourism Victoria [15-18]). All of these products rely on a consistent supply and quality of water for ongoing success. In areas where there is a significant level of agritourism, including wine tourism and other farm-based tourism activities, water is also a critical factor to the success of the enterprise. Not only do agricultural and horticultural activities consume water in order to produce their product, they can also produce significant quantities of wastewater and the addition of tourism activities to the business mix adds another factor in the water activities of the business.

The literature clearly identifies that water is a major attraction in tourism regions. However, there is also the intangible attraction that people have for water that is promoted through a significant use of water in both imagery and words. A recent South Australian tourism brochure for the Limestone Coast region devoted an entire section to water, saying 'Water may be the essence of life, but it's also the backbone of our being and the basis of boundless Limestone Coast attractions...' (South Australian Tourism Commission [19]). There is limited evidence that this aspect of water has been considered in the literature thus far.

\section{Sustainable water use in the tourism sector}

In contrast the images of water used in marketing tourism, the tourism accommodation sector has come under increasing pressure in recent years to develop a more sophisticated approach to environmental management and accreditation of their business (Jamieson et al. [20], Beeton et al. [21]). This has resulted in a range of environmental accreditation programs used across the tourism sector around the world (Font and Buckley [22], Ecotourism Australia [23], AAA Tourism [24], Green Globe [25]).

Measuring sustainability in the tourism industry is also becoming increasingly critical. Beeton et al. [21] highlighted the lack of a consistent eco-labelling system across the Australian tourism industry that has both the backing of the 
industry and the understanding of consumers. Kozak and Nield [26] discussed the limited application of eco-labelling for destinations and proposed that benchmarking could be used to measure the performance of a destination. Most recently, The Helsingborg Statement on Sustainable Tourism (Gössling [27]) recognised the need to measure the impact that tourism has on the environment.

Thus, while the literature has identified a range of environmental accreditation programs that include sustainable water use in tourism accommodation and how they impact on the choices made by tourists, there is a distinct juxtaposition between the marketing of tourism ecolabels and the marketing of water as a tourism indulgence. In dryland tourism regions understanding the impact that marketing messages may have on tourism water consumption may become a critical factor in developing sustainable water management strategies into the future.

\section{Case study method: Grampians and Wimmera Mallee accommodation enterprises}

At the time of this research, the Grampians and Wimmera region of western Victoria, as shown as area 5 in Figure 1, have been in drought for over ten years (Bureau of Meteorology [28]). Over that time there has been limited research to assess the impact of an increasingly water constrained environment on the tourism accommodation sector or on how these enterprises are managing changes to their freshwater resources.

Given the overall aim of this research is to develop sustainable freshwater management strategies for each accommodation style, the Grampians and Wimmera region provide an interesting case study to achieve this. Using a case study method for this type of research is seen as the most appropriate method as it enables the collection of comprehensive and in- depth information (Yin [29], Collis and Hussey [30]).

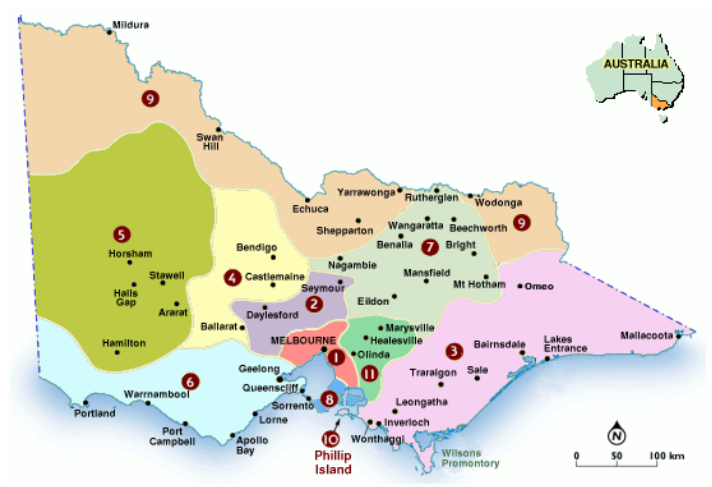

Figure 1: Map of Victoria highlighting the Wimmera and Grampians region. Source: www.travelvictoria.com.au/.../victoria.gif. 
This paper focuses on the analysis of secondary data from the water related messages contained in promotional material for the Grampians and Wimmera Mallee regions collected from Visitor Information Centres, the Internet and other media. This secondary data phase involved a content analysis (Edelheim [31], Emmison and Smith [32]) of accommodation promotional material focusing on water related issues.

Content analysis in tourism research has often been used to analyse the messages in brochures and other promotional materials (Edelheim [31], Jenkins [33]). Content analysis has also been undertaken in a tourism context on a variety of media ranging from newspapers, magazines and websites through to films and television (Crouch et al. [34]). The content analysis undertaken of the word-based data in this instance is looking for very specific references in relation to tourism and water. Each reference has been recorded and coded for analysis.

Information was collected about water-based facilities, features and management for each accommodation venue. The types of data collected from the content analysis of promotional material included the following:

- Environmental accreditation or certification

- Business accreditation or certification

- Star ratings

- References to water savings or environmentally sustainable practices

- References to business water features including pools, spas, baths, garden water features

- References to local or regional water features including lakes and rivers

- Water images used in the collateral

This information reflects which features are used in the marketing and promotion of each enterprise, thereby highlighting what the operator is most interested in promoting and what information is presented to potential guests. The results of the content analysis provided an indication of how tourism accommodation enterprises present their business in terms of water use in a tourism context. It also indicates how they seek to communicate these messages to potential guests. The analysis of this data will assist in the development of the subsequent survey (primary data phase) of accommodation enterprises and provide a comparative base from which to see if there is a relationship between the public image of the enterprise and what is actually happening in the business.

\section{Results and analysis}

Within tourism regions, including the Grampians Wimmera, there are numerous styles of accommodation. The sample for the region has been developed from brochures, websites and local signage. There were 286 accommodation enterprises included in the case study region of the Grampians Wimmera in western Victoria. The styles of accommodation were separated into Motel/hotel style, Guest house/Bed and Breakfast style, self-contained accommodation, caravan parks and camping grounds and unique or niche market accommodation styles. Of the 286 enterprises 158 were star rated by the major rating agency in 
Australia, AAA Tourism [35]. However just 10 enterprises had participated in the 'Environmentally Friendly' rating scheme despite its relatively low cost and easy entry. This would suggest that being environmentally friendly is not perceived as having a significant marketing by tourism accommodation enterprises even in an area considered to be one of the major nature-based tourism regions of Victoria (Tourism Victoria [17]).

Table 1 summarises the quantitative results of the content analysis of promotional activities undertaken by tourism accommodation providers in the case study region. Despite the Grampians and Wimmera regions having below average rainfall every year between 1996 and 2009 and being formally recognised as being in drought, more than half of the enterprises still retained images and text relating to water attractions, activities or features.

Of the water related items identified $52 \%$ of accommodation enterprises highlighted a swimming pool, $28 \%$ highlighted a spa or spa bath feature and $9 \%$ showed garden features that required significant watering. Natural features such as Mackenzie Falls, Lake Bellfield or the Wimmera River were highlighted by $22 \%$ of accommodation enterprises in their promotion and water based activities such as fishing, swimming and canoeing featured in $11 \%$. Activities often undertaken by tourists when they visit that need water, including golf, winery tourism, and spa and wellbeing treatments were featured in $16 \%$ of promotional activities. These figures are in distinct contrast to those of the environmentally friendly accreditation and suggest that tourism accommodation operators see that promoting water features, attractions and activities to potential customers is significantly more important that promoting sustainable water practices.

Table 1: Comparison of accommodation styles.

\begin{tabular}{|c|c|c|c|c|c|}
\hline $\begin{array}{c}\text { Grampians and } \\
\text { Wimmera } \\
\text { Mallee Region } \\
\text { Accommodation } \\
\text { categories }\end{array}$ & $\begin{array}{c}\text { Environ- } \\
\text { mental } \\
\text { Accreditat } \\
\text { ion }\end{array}$ & $\begin{array}{c}\text { Water } \\
\text { related } \\
\text { text or } \\
\text { images } \\
\text { used in } \\
\text { brochures } \\
\text { \% }\end{array}$ & $\begin{array}{c}\text { Water } \\
\text { related } \\
\text { text or } \\
\text { images } \\
\text { used in } \\
\text { websites } \\
\text { \% }\end{array}$ & $\begin{array}{c}\text { Water } \\
\text { related text } \\
\text { or images } \\
\text { used in } \\
\text { signage } \\
\%\end{array}$ & $\begin{array}{c}\text { Sustainable } \\
\text { water } \\
\text { messages } \\
\text { \% }\end{array}$ \\
\hline $\begin{array}{c}\text { Motels /Hotels } \\
\mathbf{7 8} \text { operators }\end{array}$ & 3 & 71 & 53 & 58 & 5 \\
\hline $\begin{array}{c}\text { Guest house } \\
\text { Bed \& Breakfast } \\
\mathbf{1 9} \text { operators }\end{array}$ & 1 & 75 & 64 & 68 & 1 \\
\hline $\begin{array}{c}\text { Self-catering } \\
\text { cabins \& units } \\
\mathbf{1 4 4} \text { operators }\end{array}$ & 1 & 32 & 23 & 36 & 1 \\
\hline $\begin{array}{c}\text { Caravan parks } \\
\text { Camping grounds } \\
\text { 29 operators }\end{array}$ & 3 & 75 & 68 & 65 & 1 \\
\hline $\begin{array}{c}\text { Niche market \& } \\
\text { Unique style } \\
\mathbf{1 6} \text { operators }\end{array}$ & 2 & 65 & 60 & 56 & 1 \\
\hline
\end{tabular}


Some specific accommodation operators clearly perceived environmental sustainability as an important part of their business promotion. The multi-award winning Boroka Downs, 5 star rated, self-contained luxury accommodation located near Halls Gap not only featured indulgence water features such as spas but also highlighted their environmental credentials, including sustainable water practices (Boroka Downs [36]). These included an overall water management plan for the property, solar hot water, water efficient shower heads, rainwater tanks, environmentally friendly cleaning products and a grey water system. At the other end of the accommodation spectrum, the Youth Hostel Association (YHA [37]) Grampians Eco Hostel, a backpacker style accommodation venue also highlighted a number of environmentally friendly features in their budgetstyle accommodation.

An interesting contrast in the luxury accommodation sector was Marwood, which included 'water pavilions' in their accommodation selection. In the example of the water pavilion the Marwood website [38] explains that 'water is pumped into a stream that babbles around the sunken lounge before flowing into the lily pond at the front door. The restful sound of water eases away stress and tension'. The Marwood operators have identified that water has an important intangible value for those guests looking for a tranquil, luxury retreat in a natural area.

A recent addition to the accommodation stocks of the region, Blaze Rock Retreat has also focussed on the idea of luxury in relation to water. One of their most prominent website images (Blaze Rock [39]) for their accommodation is a large claw-foot bath sitting at the end of the king-size bed. At the same time they also promote the water efficiency of their spa and wellbeing treatments.

Camping facilities have also had a water efficient makeover with the Victorian Government's Parks Victoria undertaking a major rejuvenation of campgrounds following the 2006 bushfires destroyed a number of them in the Grampians National Park. A recent promotion (Thomas Parkes Photography [40]) of new park facilities highlighted waterless toilets and bush showers using rain water from onsite tanks, adding to the environmental sustainability of campgrounds in the national park area.

It is clear, however, that these operators are among the exceptions rather than in the mainstream of tourism accommodation enterprises in terms of their water focus either as an environmentally sustainable operation or with a focus on indulgence. The vast majority of accommodation enterprises used a range of water-based images and text to promote their business to potential visitors but tended to utilise traditional features such as swimming pools, spas, natural attractions and water-based activities. This was despite ongoing drought conditions that impacted on many natural water features throughout the region.

\section{Conclusion}

As the first stage of a research project that is seeking to address the factors that influence tourism accommodation operators to practice sustainable use of freshwater resources in dryland regions, the main focus was in identifying the 
main focus of promotional and marketing messages used by accommodation enterprises as they related to water. At this stage there is a clear trend toward highlighting some form of water feature, attraction or activity either within the enterprise or as part of the regional attraction base.

Swimming pools remain the predominant water feature promoted in tourism accommodation marketing, although over the last decade spas and spa baths have started to emerge as a significant feature particularly in those accommodation enterprises that are specifically marketing towards couples looking for an indulgent weekend or short-break. The emergence of spas as a feature of self-contained accommodation has developed despite ongoing drought conditions over the last decade and developed in a range of accommodation levels, not just luxury five star enterprises.

Activities that require water features or significant amounts of water in order to exist, including golf, food and wine and spa and wellbeing tourism have also developed as niche markets in the Grampians and Wimmera. Again, this is despite ongoing drought conditions. However, the growing use of recycled and ground water for golf courses and in viticulture has allowed these tourism markets to develop over that period.

The next stage of this research will involve a survey of accommodation enterprises to find out about the types of sustainable water management features and activities they have undertaken in recent years. This will be followed by indepth interviews with selected enterprises that have shown some leadership in developing sustainable water management practices, to develop an understanding of those factors that have motivated their uptake of those practices. As many regions, including the Grampians Wimmera learn to live in an increasingly water constrained environment, the tourism accommodation will need to develop more sustainable water management strategies and those who are already leading the way may well provide the path for others to follow.

\section{References}

[1] UNWTO, Djerba Declaration on Tourism and Climate Change, UNWTO, 2003. World Tourism Association, Round Table No1 - Tourism and water resources, Proceedings of the $1^{\text {st }}$ International Conference on Climate Change and Tourism.

[2] UNWTO \& UNEP 2008, Climate Change and Tourism: Responding to Global Challenges, UNWTO \& UNEP, Paris \& Madrid.

[3] United Nations Environment Program, Tourism's three main impact areas, viewed 21 February 2009. http://www.unep.fr/scp/tourism/sustain/ impacts/environmental/mainareas.htm.

[4] National Long-Term Tourism Strategy Steering Committee, 2009, The Jackson Report, Commonwealth of Australia, Barton, ACT.

[5] Hadwen, W, Arthington, A., Boon, P., Lepesteur, M \& McComb, A. 2006, Rivers, Streams, Lakes and Estuaries, hot spots for cool recreation and tourism in Australia, CRC for Sustainable Tourism Pty Ltd. 
[6] Anderson, S. (2002). The Pleasure of Taking the Waters. In S. Anderson and B. Tabb (Eds.), Water, Leisure \& Culture (pp.1-6). Oxford, Berg.

[7] Cooper, C. (2006). Lakes as Tourism Destination Resources. In C.M. Hall and T. Härkönen, (Eds.), Lake Tourism, An Integrated Approach to Lacustrine Tourism Systems (pp.27-44). Clevedon, Channel View Publications.

[8] Tuohino, A. (2006). Lakes as an Opportunity for Tourism Marketing: In Search of the Spirit of the Lake. In C.M. Hall and T. Härkönen, (Eds.), Lake Tourism, An Integrated Approach to Lacustrine Tourism Systems (pp.101-118). Clevedon, Channel View Publications.

[9] Goossen, M. (2006). Lake Tourism in the Netherlands. In C.M. Hall and T. Härkönen, (Eds.), Lake Tourism, An Integrated Approach to Lacustrine Tourism Systems (pp.119-130). Clevedon, Channel View Publications.

[10] Prideaux, B., Timothy, D. and Cooper, M. (2009). Introducing River Tourism: Physical, Ecological and Human Aspects. In B. Prideaux and M. Cooper (Eds.), River Tourism (pp. 1-22). Wallingford, CABI.

[11] Efurt-Cooper, P. (2009). European Waterways as a Source of Leisure and Recreation. In B. Prideaux and M. Cooper (Eds.), River Tourism (pp. 95116). Wallingford, CABI.

[12] Rico-Amoros, A.M, Olcina-Cantos, J. \& Sauri, D. 2009, 'Tourist land use patterns and water demand: Evidence from the Western Mediterranean.' Land Use Policy 26 pp 493-501.

[13] Goodwin, H. \& Walters, K. 2007, World Travel market 'No Water no Future' Report, International Centre for Responsible Tourism, Leeds Metropolitan University.

[14] Hudson, B 1998, Waterfalls: Resources for Tourism. Annals of Tourism Research, Vol. 25, No.24, 958-973, 1998.

[15] Tourism Victoria 2003, Victoria's Tourism Plan Summary, Food and Wine 2004-2007, Tourism Victoria, Melbourne.

[16] Tourism Victoria 2004, Victoria's Spa and Wellness Tourism Action Plan 2005-2010, Tourism Victoria, Melbourne.

[17] Tourism Victoria 2007, Nature Based Tourism Strategy 2008-2012, Tourism Victoria, Melbourne.

[18] Tourism Victoria 2008, Victoria's Golf Tourism Action Plan 2009-2012, Tourism Victoria, Melbourne.

[19] South Australian Tourism Corporation 2009, South Australia Limestone Coast, pp.18-19.

[20] Jamieson, W., Kelovkar, A., Sunalai, P. \& Mandke, P. 2003, A Manual for Water and Waste Management: What the Tourism Industry Can Do to Improve its Performance, United Nations Environment Programme, Paris.

[21] Beeton, S., Bergin-Seers, S. \& Lee, C. 2007, Environmentally Sustainable Practices of Victorian Tourism Enterprises, Sustainable Tourism CRC, Gold Coast.

[22] Font, X \& Buckley, R. 2001, Tourism Ecolabelling: certification and promotion of sustainable management. Wallingford, CABI Publishing. 
[23] Ecotourism Australia, Eco Certification Program, Viewed 24 June 2008. $<$ http://www.ecotourism.org.au/eco_certification.asp $>$

[24] AAA Tourism, Eco-Friendly Star Accreditation, viewed 17 September 2009. <http://www.aaatourism.com.au/about-star-ratings/star-eco/>

[25] Green Globe, Earthcheck, Viewed 2 October 2009. <http:// www.ec3global.com/products-programs/green-globe/Default.aspx $>$

[26] Kozak, M \& Nield, K., The Role of Quality and Eco-labelling Systems in Destination Benchmarking. Journal of Sustainable Tourism, 12, 2 pp.138148,2004

[27] Gössling, S., The Helsingborg Statement on Sustainable Tourism. Journal of Sustainable Tourism, 16,1 pp.122-124, 2008

[28] Bureau of Meteorology, Living with Drought, viewed 18 February 2009.<http://www.bom.gov.au/climate/drought/livedrought.shtml $>$

[29] Yin, R.K. 2003. Case Study Research - Design and Methods. Sage Publications, Thousand Oaks, California.

[30] Collis, J. \& Hussey, R. 2008, Business Research A Practical Guide for Undergraduate and Postgraduate Students. $3^{\text {rd }}$ edition, Palgrave Macmillan, Basingstoke.

[31] Edelheim, J. 2007, Hidden Messages - a polysemic reading of tourist brochures, School of Tourism and Hospitality Management Papers, Southern Cross University, ePublications

[32] Emmison, M \& Smith, P. 2007, Researching the Visual, Sage Publications, London.

[33] Jenkins, O. (2003). Photography and travel brochures: the circle of representation. Tourism Geographies 5(3), 305-328.

[34] Crouch, D. Jackson, R and Thompson, F (2005). The Media and the Tourist Imagination. Abingdon, Routledge.

[35] AAA Tourism, Grampians, VIC Accommodation, viewed 17 September 2009.<http://www.aaatourism.com.au/accommodation/search/location/ grampians/>

[36] Boroka Downs, About Boroka...our environment, viewed 4 October 2009 $<$ http://www.borokadowns.com.au/?id=aboutborokadowns $>$

[37] YHA Australia, Halls Gap Victoria, viewed 4 October $2009<$ http:// www.yha.com.au/hostels/details.cfm?hostelid=93\&CFID $=5913435 \&$ CFTOKEN $=92273622 \&$ jsessionid=f0306e376932459fe90a7a55761c25539 7f $2>$

[38] Marwood, Water Pavilions, viewed 4 October, $2009<$ http:// www.marwood.net.au/>

[39] Blaze Rock, Accommodation, viewed 4 October 2009.<http:// www.blazerock.com.au/?id=accommodation>

[40] Thomas Parkes Photography, viewed 4 October $2009<$ http:// thomasparkes.wordpress.com/2009/07/12/grampians-np-campgroundinfrastructure-upgrade/> 